\title{
Gingival Granular Cell Tumor of the Newborn: A Case Report and Review of Literature
}

\author{
Yenidoğanda Gingival Granüler Hücreli Tümör: \\ Olgu Sunumu ve Literatürün Gözden Geçirilmesi
}

\author{
Adalat HASANOV', Jamal MUSAYEV', Binnur ÖNAL³, Chingiz RAHIMOV², Ismayil FARZALIYEV² \\ Departments of ${ }^{1}$ Pathology and ${ }^{2}$ Oral and Maxillofacial Surgery, Azerbaijan Medical University, BAKU, AZERBAIJAN, \\ ${ }^{3}$ Department of Pathology and Cytology, M.H. Ankara Dışkapı Yıldırım Beyazıt Training and Research Hospital, ANKARA, TURKEY
}

\begin{abstract}
The etiology and histogenesis of granular cell tumor are still debated. Granular cell tumor of the newborn is considered to be a different entity than the adult form of this lesion with different immunohistochemical features. We present a case of a rare gingival granular cell tumor in a newborn and review the literature. Gingival granular cell tumor must be clinically differentiated from teratoma, congenital dermoid cyst, congenital fibrosarcoma, hemangioma, lymphangioma, leiomyoma, rhabdomyoma, heterotopic gastrointestinal cyst, congenital cystic choristoma and congenital lipoma. Surface ulceration or pseudoepitheliomatous hyperplasia may lead to confusion with malignancy.
\end{abstract}

Key Words: Granular cell tumor, Gingiva, Newborn

\section{ÖZ}

Granüler hücreli tümörün etiyolojisi ve histogenezi tartışılmaktadır. Yeni doğanda granüler hücreli tümörün, farklı immünohistokimyasal özellikleri ile erişkinde görülenden ayrı bir antite olduğu savunulmaktadır. Bu makalede, yenidoğan döneminde nadir gözlenen gingival granüler hücreli tümöre ait bir olgu sunulmuş ve literatür gözden geçirilmiştir. Gingival granüler hücreli tümör klinikte, teratom, konjenital dermoid kist, konjenital fibrosarkom, hemanjiom, lenfanjiom, leyomiyom, rabdomiyom, heterotopik gastrointestinal kist, kongenital kistik koristom ve kongenital lipomdan ayırt edilmelidir. Yüzeyinde ülserasyon ya da psödoepitelyomatöz hiperplazi olduğunda malignite ile karışabilir.

Anahtar Sözcükler: Granüler hücreli tümör, Gingiva, Yenidoğan

\section{INTRODUCTION}

Granular cell tumor (GCT), known as Neuman tumor, Abrikosov tumor or granular cell myoblastoma in the medical literature, is quite rare in the newborn period. The etiology and histogenesis of the tumor are controversial. Newborn GCT is a different entity than in the adult with different immunohistochemical features (1).

We present a rare case of newborn GCT and review the literature.

\section{CASE REPORT}

A smooth surfaced, non-fixated mass developing from the gingival mucosa was found on the frontal section of the mandibular alveole on the 6th postnatal day of a female child who was born at the Azerbaijan Medical University following 34-week gestation with a birth weight of $3400 \mathrm{gr}$

Received : 26.08.2010

Accepted : 10.11 .2010 and height of $49 \mathrm{~cm}$ through the spontaneous vaginal route (Figure 1). The mass prevented feeding and was therefore surgically removed under general anesthesia. No other lesions or systemic involvement was found. There were no complications during 12-month follow-up.

Macroscopic evaluation revealed a smooth-surfaced, widebased polypoid lesion $18 \times 14 \times 13 \mathrm{~mm}$ in size and covered by gray-white mucosa. Histopathological evaluation showed a tumor mass with monotonous appearance consisting of round-polygonal cells with a large eosinophilic cytoplasm and oval, innocent looking nuclei that was covered by normal multilayered epithelium on the surface (Figures $2,3)$. There were no atypical features, mitosis or necrosis. No tumor was seen at the surgical margins. Histochemical investigation revealed no PAS positivity in the tumor. The immunohistochemical investigations with S100, CD68, desmin, MSA, myogenin, SMA and NSE were also negative.

Correspondence: Jamal MUSAYEV

Department of Pathology, Azerbaijan Medical University,

BAKU, AZERBAIJAN

E-mail: patolog.jamalmusaev@gmail.com Phone: +009 94124302850 


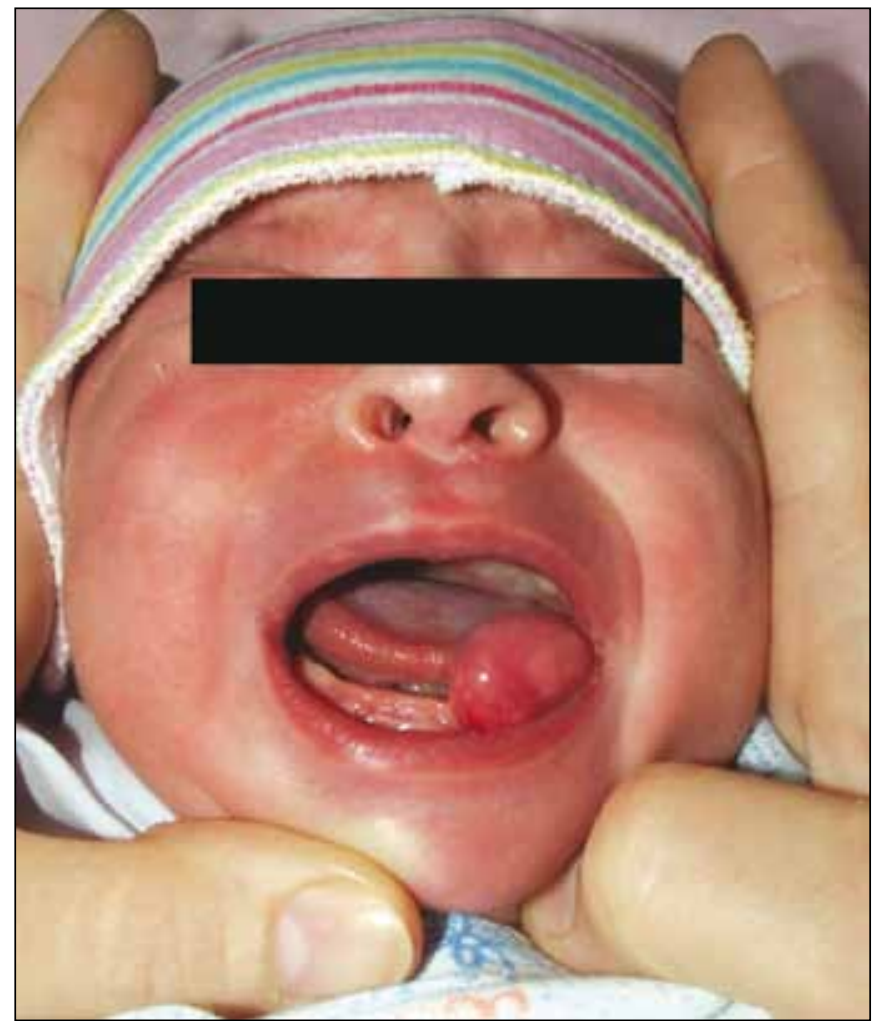

Figure 1: Mass at the frontal section of the mandibular alveole.

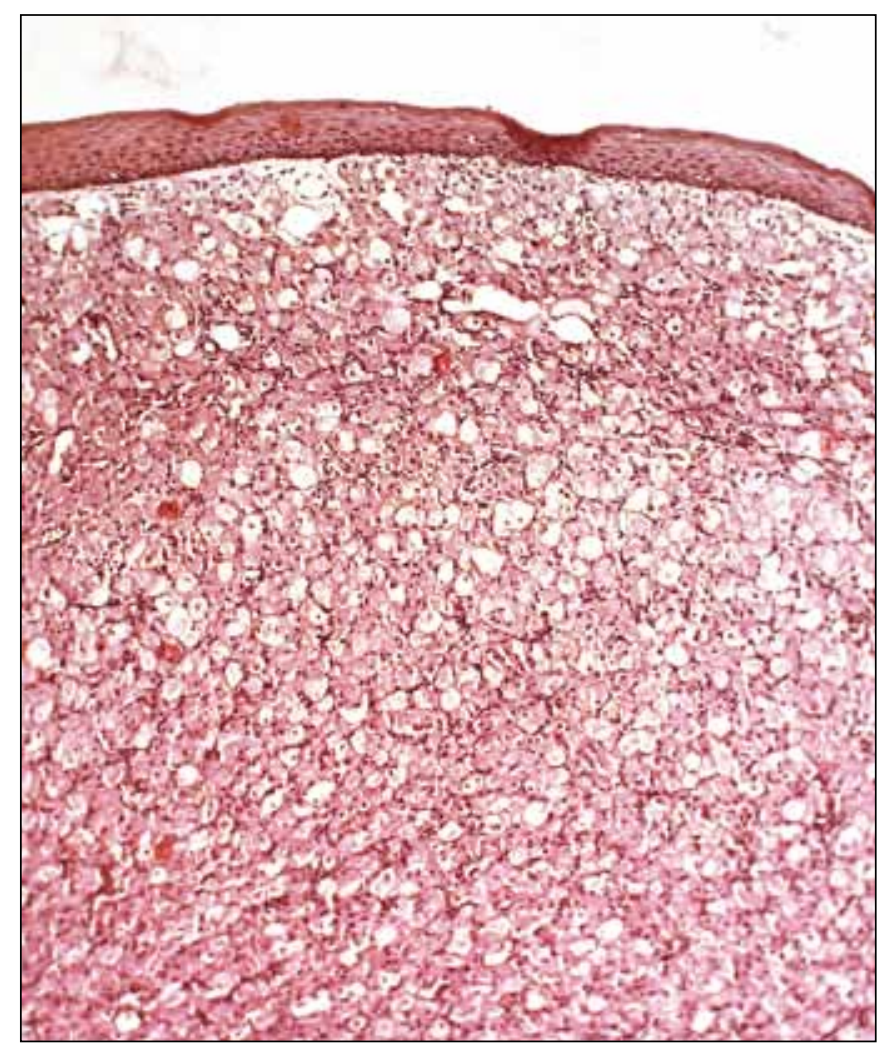

Figure 2: Tumor tissue under surface stratified squamous epithelium (H\&E, x100).

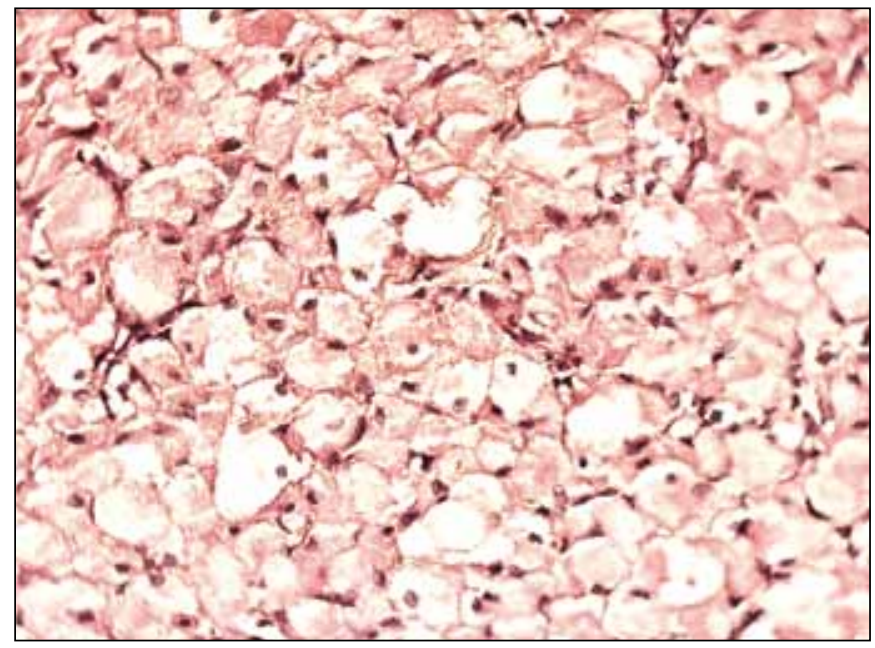

Figure 3: Granular cell tumor (H\&E, x400).

\section{DISCUSSION}

GCT has first been described in 1871 as "congenital epulis" by Neumann (2). Later studies concentrated on the striated muscle and neurogenic origin of the tumor $(3,4)$. The tumor is also postulated to originate from indifferentiated mesenchymal cells, fibroblasts, myofibroblasts, histiocytes, Schwann cells or odontogenic epithelial cells (5). GCT is now known as a benign mesenchymal tumor of unknown origin.

Recurrence is rare and metastasis is not seen in GCT cases. The common locations are the tongue in the adult and the gingiva in the newborn as in our case. The maxillary to mandibular alveole ratio is 3 to 1 in the newborn and the tumor is usually close to the midline. GCT lesions are usually single but can be multiple in $5-16 \%$ of cases. The mandibular and maxillary alveoli are the most common locations for multiple cases as well $(6,7)$. The female/male child ratio is $8: 1(6,8,9)$.

The immunohistochemical profile of the tumor is different in newborns and adults. This tumor is a variant of the granular cell tumor and is S-100 negative immunohistochemically and does not show any differentiation specific to any cell type $(1,10)$. Our case was also negative with the S-100 immune marker.

These lesions are thought to develop reactively with the effect of maternal hormones and may show a tendency to become smaller in the newborn period as the maternal hormones decrease. They do not recur after excision $(6,11$ 14). Our case also did not show any recurrence within 12 months after excision. 
The clinical differential diagnosis of GCT includes congenital dermoid cyst, congenital fibrosarcoma, hemangioma, lymphangioma, leiomyoma, rhabdomyoma, heterotopic gastrointestinal cyst, congenital cystic choristoma and congenital lipoma. Congenital GCT is covered with normal oral mucosa and is hard while hemangiomas and lymphangiomas are "spongy" on palpation and have a red or dark blue surface. Doppler ultrasonography can be used for the differential diagnosis. Finding fluctuation on palpation and the ultrasonographic findings may help in the differential diagnosis of GCT and cystic lesions. Cystic GCT has not previously been reported. Radiological findings related to lesion margins and associated with bony tissue are important regarding the differential diagnosis of GCT and solid tissue tumors, especially when eliminating malignancy. Radiologically, GCT lesions have regular and prominent margins with no association with bony tissue.

Pseudoepitheliomatous hyperplasia of the oral mucosa on the tumor surface is seen in approximately half of adult GCT cases but is usually not seen in newborn GCT cases. Cases with accompanying pseudoepitheliomatous hyperplasia or ulceration may be confused with squamous cell carcinoma (10).

Malignant GCT makes up 1-2\% of the cases and the main differential diagnosis is alveolar soft part sarcoma. There are no malignant congenital GCT cases reported in the literature.

The profuse cellularity and prominent nucleoles in isolated cells in the lesion on cytopathological investigation can lead to mimicking of any common malignant lesion in the oral cavity and a false positive diagnosis. Histopathology is the gold standard in the diagnostic process.

\section{ACKNOWLEDGEMENTS}

We would like to thank Prof. Dr. Diclehan Orhan from Hacettepe University, Medical Faculty, Department of Pediatric Pathology for her contribution.

\section{REFERENCES}

1. Hoshi N, Tsu-ura Y, Watanabe K, Suzuki T, Kasukawa R, Suzuki T: Expression of immunoreactivities to $75 \mathrm{kDa}$ nerve growth factor receptor, trk gene product and phosphotyrosine in granular cell tumors. Pathol Int 1995, 45:748-756

2. Neumann E: Ein fall von kongenitaler Epulis. Arch Heilkd 1871, 12:189-190

3. Kamal SA, Othman EO: Granular cell tumour of the larynx. J Laryngol Otol 1998, 112:83-85

4. Holland RS, Abaza N, Balsara G, Lesser R: Granular cell tumor of the larynx in a six-year-old child: case report and review of the literature. Ear Nose Throat J 1998, 77:652-654

5. Godra A, D'Cruz CA, Labat MF, Isaacson G: Pathologic quiz case: a newborn with a midline buccal mucosa mass. Congenital gingival granular cell tumor (congenital epulis). Arch Pathol Lab Med 2004, 128:585-586

6. Lack EE, Worsham GF, Callihan MD, Crawford BE, Vawter GF: Gingival granula cell tumors of the newborn (congenital "epulis"): a clinical and pathologic study of 21 patients. Am J Surg Pathol 1981, 5:37-46

7. Charrier JB, Droullé P, Vignaud JM, Chassagne JF, Stricker M: Obstructive congenital gingival granular cell tumor. Ann Otol Rhinol Laryngol 2003, 112:388-391

8. Inan M, Yalçin O, Pul M: Congenital fibrous epulis in the infant. Yonsei Med J 2002, 43:675-677

9. Bilen BT, Alaybeyoğlu N, Arslan A, Türkmen E, Aslan S, Celik M: Obstructive congenital gingival granular cell tumour. Int J Pediatr Otorhinolaryngol 2004, 68:1567-1571

10. Regezi JA, Sciubba JJ, Jordan RCK: Oral pathology: Clinical pathologic correlations. 5th ed., St. Louis, Elsevier Saunders, 2008, 168-170

11. Park SH, Kim TJ, Chi JG: Congenital granular cell tumor with systemic involvement. Immunohistochemical and ultrastructural study. Arch Pathol Lab Med 1991, 115:934-938

12. Tucker MC, Rusnock EJ, Azumi N, Hoy GR, Lack EE: Gingival granular cell tumors of the newborn. An ultrastructural and immunohistochemical study. Arch Pathol Lab Med 1990, 114: 895-898

13. Fletcher CDM: Peripheral neuroectodermal tumors. In: Diagnostic Histopathology of Tumors, ed. Fletcher CDM. 2nd ed., London, Churchill Livingstone, 2000, 1679-1711

14. Jenkins HR, Hill CM: Spontaneous regression of congenital epulis of the newborn. Arch Dis Child 1989, 64:145-147 